\title{
A magyarországi öngyilkossági halálozás változásai a COVID-19-járvány első évében
}

\author{
Osváth Péter dr. ${ }^{1}$ - Bálint Lajos dr. ${ }^{2,3}$ - Németh Attila dr. ${ }^{4}$ \\ Kapitány Balázs ${ }^{2}$ - Rihmer Zoltán dr. ${ }^{4,5}$. Döme Péter dr., ${ }^{4}$ \\ ${ }^{1}$ Pécsi Tudományegyetem, Általános Orvostudományi Kar, Pszichiátriai és Pszichoterápiás Klinika, Pécs \\ ${ }^{2}$ Központi Statisztikai Hivatal, Népességtudományi Kutatóintézet, Budapest \\ ${ }^{3}$ Pécsi Tudományegyetem, Bölcsészettudományi Kar, Szociológia Tanszék, Pécs \\ ${ }^{4}$ Országos Mentális, Ideggyógyászati és Idegsebészeti Intézet, Budapest \\ ${ }^{5}$ Semmelweis Egyetem, Általános Orvostudományi Kar, Pszichiátriai és Pszichoterápiás Klinika, Budapest
}

\begin{abstract}
Bevezetés: Az öngyilkosság fó rizikófaktorának a pszichiátriai zavarokat tekintjük. A COVID-19 többek között neuropszichiátriai kórképek kialakulásához is vezethet. Ezen túl a pandémia egyéb velejárói, mint például az izoláció vagy a munkahelyvesztés, a társadalom egészséges tagjaiban is stresszhez, végül pszichiátriai zavarokhoz vezethetnek. Célkitüzés: Vizsgálatunk célja annak a teóriának a tesztelése volt, hogy a fenti tényezők miatt együtt járt-e a járvány a hazai suicid halálozás csökkenő trendjének irányváltásával.

Módszer: Vizsgálatunkban a megszakított idősorok elemzésének módszerét használtuk, a becslésekhez kvázi-Poissonregressziót alkalmazva, hogy összehasonlítsuk a 2010 és 2020 közötti időszak havi bontású adataiból kirajzolódó trendek alapján a járvány időszakában (2020. március-december) „elvárt” öngyilkossági esetszámokat a ténylegesen bekövetkezett esetek számával.

Eredmények: A COVID-19-hónapok alatt a férfiak által elkövetett öngyilkosságok száma szignifikánsan, 18\%-kal nőtt, ahhoz a trendhez képest, amely a COVID-19 hiányában állt volna elő. A teljes populációban szintén szignifikáns, 16\%-os emelkedést lehetett megfigyelni, míg a nők által elkövetett öngyilkosságok száma nem tért el szignifikánsan a pre-COVID-19-időszak trendje alapján elvárt értéktől.

Megbeszélés és következtetés: A járvány kitörése utáni időszakban a magyar férfiak szignifikánsan gyakrabban követtek el öngyilkosságot, míg a nőknél az adatok nem tükröztek lényegi változást. A más országokban kivitelezett vizsgálatok eredményei érdekes módon inkább csökkenést vagy nem szignifikáns változást jeleztek, amikor a COVID-19-éra suicid számait az azt megelőző időszakok számaival hasonlították össze. A hazai és a nemzetközi eredmények közti eltérések magyarázata egyelőre még nem ismert, így a téma mindenképpen további vizsgálatokat igényel. Orv Hetil. 2021; 162(41): 1631-1636.
\end{abstract}

Kulcsszavak: suicidium, COVID-19, Magyarország, öngyilkosság

\section{Changes in suicide mortality of Hungary during the first year of the COVID-19 pandemic}

Introduction: Psychiatric disorders are the main risk factors for suicide. COVID-19 may result in the appearance of neuropsychiatric syndromes. Moreover, other corollaries of the pandemic (e.g., isolation, job loss) may lead to increasing stress and, ultimately, psychiatric disorders even among the non-infected population.

Objective: We aimed to test the theory of whether the pandemic, due to the aforementioned factors, was associated with the reversal of the declining suicide rate trend in Hungary.

Method: To compare the observed number of suicides during the COVID-19 months (March-December 2020) with the expected numbers, we used an interrupted time series model and, for the estimations, quasi-Poisson regression. Expected numbers were calculated based on trends derived from monthly data between 2010 and 2020.

Results: During the months of the pandemic, the number of suicides among males rose significantly by $18 \%$ compared to the hypothetical trend that would have occurred in the absence of COVID-19. A significant increase (16\%) was also observed in the total population. By contrast, the number of female suicides did not differ significantly from the number expected based on the pre-COVID-19 trend. 
Discussion and conclusion: After the outbreak of the epidemic, Hungarian males committed significantly more suicides, while no relevant changes were observed among females. Interestingly, studies from other countries found either no change or decrease when comparing suicide numbers from the COVID-19 period with the corresponding numbers from the pre-COVID-19 period. The explanation for this discrepancy is still lacking, so further investigations are needed.

Keywords: suicide, COVID-19, Hungary

Osváth P, Bálint L, Németh A, Kapitány B, Rihmer Z, Döme P. [Changes in suicide mortality of Hungary during the first year of the COVID-19 pandemic]. Orv Hetil. 2021; 162(41): 1631-1636.

(Beérkezett: 2021. július 2.; elfogadva: 2021. július 29.)

\begin{abstract}
Rövidítések
ARDS $=$ (acute respiratory distress syndrome $)$ akut légzőszervi distressz szindróma; COVID-19 = (coronavirus disease 2019) koronavírus-betegség 2019; HKUl = Hong Kong University-1 béta-koronavírustörzs; $\mathrm{KI}=$ konfidenciaintervallum; MERS- $\mathrm{CoV}=$ (Middle East respiratory syndrome coronavirus) a közel-keleti légúti szindrómát okozó koronavírus; OC43 = (organ culture 43) béta-koronavírustörzs; SARS-CoV-2 = (severe acute respiratory syndrome coronavirus 2) súlyos akut légzőszervi szindrómát okozó koronavírus-2
\end{abstract}

A COVID-19-járvány 2019 végén Vuhanban (Kína) tört ki [1]. Hazánkban az első esetet hivatalosan 2020. március 4-én, míg az első halálesetet március 15-én regisztrálták [2]. A WHO 2020. január 30-án „nemzetközi aggodalomra okot adó közegészségügyi veszélyhelyzetet" hirdetett ki, majd március 11-én a COVID19-járványt pandémiának minősítette [3]. A fertőzés ágenseként egy új, a későbbiekben SARS-CoV-2-ként elnevezett béta-koronavírust azonosítottak, mely közeli rokonságban áll két potenciálisan súlyos, akár ARDS-sel járó kórképet okozó humán béta-koronavírussal (MERSCoV, illetve SARS-CoV), illetve néhány, enyhe lefolyású légúti megbetegedést okozó humán béta-koronavírussal (HKU1, OC43) [4-9]. A COVID-19 elsősorban a tüdőt, ritkábban a gastrointestinalis rendszert, a szívet, a vesét és a májat károsítja, de okozhat coagulopathiát, továbbá jelentkezhetnek bőrelváltozások és conjunctivitis, illetve egyéb szervek - többek közt a perifériás és a központi idegrendszer - múködészavara is $[6,10]$. Az utóbbi kapcsán elmondható, hogy a COVID-os esetek viszonylag nagy részében (kb. 20-80\%) változatos neuropszichiátriai tünetek, illetve kórképek jelennek meg, így például anosmia, dysgeusia, encephalopathia, stroke vagy encephalitis, továbbá depresszió és szorongás $[6,7,11-14]$. A központi idegrendszer múködészavara többféle mechanizmussal jöhet létre. Egyrészt a vírus direkt módon képes károsítani a központi idegrendszert, amit alátámaszt, hogy a SARS-CoV-2 örökítőanyagát (és immunhisztokémiai módszerekkel magát a vírust is) kimutatták néhány esetben az agyban (és nagyon ritkán a cerebrospinalis folyadékban is). A ví- rus feltételezhetóen hematogén szóródással, esetleg közvetlenül, a bulbus olfactoriuson keresztül jut el a központi idegrendszerbe $[7,11,12]$. Másrészt, túl a vírusnak az előbbiekben részletezett direkt, központi idegrendszert károsító hatásán, a COVID-19 indirekt módon (azaz a fertőző ágensnek a központi idegrendszerbe való eljutása nélkül) is megzavarhatja a központi idegrendszer múködését, amit egyrészt mediálhat a COVID-dal asszociálódó szisztémás hypoxia, illetve citokinvihar, de a coagulopathia miatt kialakuló stroke-ok is $[7,12,14]$.

A COVID-19-járványnak - az elóbbiekben részletezett direkt (a vírus neurotrop jellegéből fakadó) és indirekt (hypoxia, citokinvihar kapcsán kialakuló), központi idegrendszert károsító hatásain túl - olyan, nem biológiai-élettani, hanem szociális és egyéb hatásaival is számolni kell, melyek az egyének stressz-szintjét növelik, és így végső soron szintén pszichés problémákban, majd önsértő magatartásban ölthetnek testet $[12,14,15]$. Ilyen, stresszt kiváltó faktorként gondolhatunk például a kijárási korlátozásokból fakadó izolációra, a munka- és életkörülmények radikális megváltozására (például a „home office"-ra és a „homeschooling”-ra való áttérésre, emiatt a családok összezártságára), az esetleges munkahelyvesztésre (és az ezzel járó jövedelemkiesésre), a megfertőződéstôl való félelemre, a hozzátartozó megbetegedésére/ halálára vagy az amiatti aggodalomra, hogy lebetegedve terhet jelentünk majd mások számára. További problémát jelenthet a betegek és családtagjaik stigmatizációja. A COVID-19-járvány miatt az egészségügyi ellátórendszer fokozott leterheltsége potenciálisan rontja a krónikus pszichiátriai betegek hozzáférését az ellátáshoz, ami állapotuk rosszabbodásához vezethet [14-16]. A járványnak ezen - az egyszerűség kedvéért itt „szociálisnak" nevezett - hatásai közül némelyik ráadásul a nem COVID-19-fertőzötteket is érinti, így káros következményeik a társadalom jóval szélesebb rétegeiben tudnak érvényesülni.

A suicidium multifaktoriális hátterú jelenség, vagyis bekövetkezésének esélyét többféle - egymástól sem független - tényező határozza meg, melyek közül az egyik legfontosabb a kurrens major depressziós epizód [17]. Metaelemzésből származó eredmény alapján a COVID-os 
betegek közt a depresszió pontprevalenciája messze meghaladja a populációs átlagot $(23 \%$ vs. $4 \%)$, így csupán ezt az egy faktort figyelembe véve azt várhatnánk, hogy a populáció suicid rátája is növekszik a járvány során [13, 18]. Ugyanakkor, éppen a suicidium már említett multifaktoriális jellege, illetve amiatt, hogy a járvány egyszerre nagyon sok rizikó- és néhány esetben protektív faktort „mozgat”, a valós helyzet ennél sokkal komplexebb, így nehéz prognosztizálni, hogy a pandémia miatt megváltozott számtalan körülmény végül is valóban a suicid ráta emelkedéséhez vezet-e. Az eddig megjelent nemzetközi vizsgálatok eredményei visszatükrözik ezt a feltételezést, mivel a COVID-19 hatása az öngyilkossági halálozás növekedésére korántsem egyértelmú, sőt inkább azok az eredmények vannak túlsúlyban, amelyek csökkenésre vagy az érdemi változás hiányára utalnak [19, 20]. Így például egy vizsgálat az öngyilkosságok számának csökkenését írta le Ausztria Tirol tartományában a járvány első 6 hónapjában (2020. április-szeptember) [21]. Egy Anglia népességének kb. a negyedét (13 millió fö) kitevő mintából származó adatsorokat feldolgozó vizsgálat szintén nem talált emelkedést a suicidiumok számában a lezárást követő 7 hónapos, 2020. áprilistól októberig tartó időszakban [22]. A járvány első hét hónapjában Ausztrália Queensland régiójában [23], illetve első hat hónapjában a kanadai British Columbia tartományban szintén nem észleltek emelkedést az öngyilkossági halálozás vonatkozásában [24]. Egy 21, magas jövedelmú (például Ausztrália, Ausztria, Kanada, Chile, Horvátország, Észtország, Olaszország), illetve közepes jövedelmû (például Oroszország, Brazília, Ecuador, Mexikó) ország adatait feldolgozó tanulmány ugyancsak arra a következtetésre jutott, hogy a járvány kezdeti időszakában változatlan maradt vagy éppen csökkent az öngyilkosságok száma [25]. Lipcse (Németország) suicid rátája sem változott a járvány idején, a korábbi évek kijelölte trendhez képest (a szerzők csak a járvány első hónapjait, 2020. március-szeptember, vonták be elemzésükbe) [19, 26]. A spanyolországi Extremadura régióban, a 2020. márciustól októberig terjedő időszak öngyilkossági esetszámait elemezve sem találtak eltérést a korábbi években megfigyelt esetszámokhoz képest [19]. Két japán vizsgálat eredményei némileg eltérnek az eddig ismertetettektől, mivel ezek csak a járvány első hónapjaiban (2020. február-június) regisztráltak csökkenést, de ezt követően a ráta emelkedését észlelték, amely elsősorban a nók közt volt kifejezett (a szerzők a nemi különbséget a nők közötti nagyobb arányú munkahelyvesztéssel és a családon belüli erőszak fokozódásával magyarázták) $[27,28]$. A csökkenő suicid halálozást a járvány kezdeti időszakában magyarázhatja a társadalmi kohéziónak (azaz a közösségi összefogásnak) a külső fenyegető tényező megjelenése miatti megerősödése, amint ezt egyes természeti katasztrófák, terrortámadások és háborúk esetén is megfigyelték, és ahogyan azt már a tudományos igényü suicidologia egyik alapítójaként tisztelt Émile Durkheim is feltételezte a 19. században $[14,20,21$,
26]. Ugyanakkor úgy túnik, hogy ez az (átmeneti?) csökkenés nem feltétlenül jelenik meg, hiszen például a „spanyolnátha” első hullámát követően egy vizsgálat növekvő suicid rátákat talált, míg a második hullám után már nem volt megfigyelhető érdemi eltérés, illetve a COVID-19 kapcsán már hivatkozott spanyol tanulmány szerint sem a járvány első (2020. március-június), sem a második (2020. július-október) szakaszának esetszámai nem tértek el szignifikánsan az előző 5 év átlagától [16, 19-21, 29]. Továbbá, a 2002-2003-ban zajló SARS-járvány kapcsán emelkedett suicid esetszámokat találtak, de csak az idős populáció vonatkozásában [8, 16, 29]. Ha megjelenik is kezdetben a társadalom egészét érintő katasztrófahelyzetek után a suicid ráta csökkenése, ez valószínúleg csak átmeneti módon történik meg, ahogy arra a két, már említett japán vizsgálat eredményei a COVID-19 kapcsán is utaltak [20, 21, 26-29].

Mivel az eddig publikált külföldi vizsgálatok nagy része a járvány kezdeti néhány hónapjára fókuszált, illetve tudomásunk szerint hazai adatokon még nem vizsgálták, hogy a ragály kitörése együtt járt-e a befejezett öngyilkosságok számának változásával, célkitűzésünk ennek a kérdésnek a megválaszolására irányult.

\section{Módszer}

A megszakított idősorok elemzése (interrupted timeseries analysis) gyakran alkalmazott módszer a COVIDjárvány öngyilkosságra gyakorolt hatásának vizsgálatára $[23,25]$. Az elemzés során az öngyilkosság havi gyakoriságú idősorára támaszkodtunk, amelyet a COVID-járvány 2020 márciusában „megszakított”. A hipotetikus forgatókönyv szerint a „beavatkozás” (esetünkben a COVID-járvány) hiányában a trend változatlanul, a meglévő tendenciáknak megfelelően folytatódna. Ezt a tényellentétes (kontrafaktuális) szcenáriót vetjük össze a „beavatkozást” követő időszak tényleges változásaival, ami lehetővé teszi a járvány hatásának értékelését. Az elemzés jelenlegi fázisában pusztán a „beavatkozás” hatását vizsgáltuk, más strukturális indikátort nem vettünk figyelembe. A „beavatkozás” szerepét kétértékú 'dummy’ változó írja le, amely „0” volt a COVID-19 előtti időszakban, és „l”-es értéket kapott 2020 márciusától 2020 decemberéig.

Az elemzés megfigyelési egysége a havi bontású öngyilkossági esetszám volt. Az elemzés kiinduló módszere a Poisson-regresszió volt. A logaritmustranszformált népesség az egyenlet jobb oldalán szerepel ('offset' változó). Mivel a hazai suicid idősorok az elemzett időszakban jelentős éves csökkenést és havi ingadozást mutatnak, szükségszerű volt a trend és a szezonális hatások kezelése. A trend esetében lineáris trendet, a szezonális ingadozás esetében hónap 'dummy'-kat, illetve szinusz-, koszinuszpárokat tartalmazó periodikus függvényeket (Fourier-tagok) használtunk fel. Mivel a modellek eredményei a szezonalitás kezelésének függvényében nem különböztek, csak az utóbbi megoldás eredményeit fog- 
juk bemutatni. A kiinduló Poisson-modell feltételezi, hogy az eredményváltozó varianciája megegyezik a Poisson-eloszlás által előre jelzett értékkel; az azonos szórásfeltevés azonban egyetlen modell esetében sem teljesült, így végül, a túlszóródás miatt, kvázi-Poisson-modell alkalmazása mellett döntöttünk.

Az adatállomány a 2010 és 2020 közötti évek havi bontású öngyilkossági adatait tartalmazza. A vizsgált 132 hónapban 21463 befejezett öngyilkosság történt Magyarországon, az elkövetők 76,2\%-a (16 357) férfi, 23,8\%-a nő (5106) volt. Néhány év kivételével az öngyilkossági esetszámok folyamatosan csökkentek. A koronavírus-járvány első évében, azaz 2020-ban a férfiesetszámok a megelőző évhez képest 1158-ról 1311-re nőttek, míg a nőknél lényegében nem történt változás, az esetszámok nem változtak (2019-ben 392, 2020-ban 395 öngyilkosság történt).

\section{Eredmények}

A modelleket nemek szerint külön-külön és a populáció egészére futtattuk le (1. táblázat). A magyarázó változók közül a hónapok sorszámát (1., .., 132.) tartalmazó időváltozó a suicid esetszámok csökkenésének havi ütemét írja le. Számunkra lényegi jelentéssel a járvány hatását leíró COVID-19 változó bír. Eredményeink alapján az öngyilkosság szintje a járvány időszakában nem változott a nőknél (1. táblázat; 1. ábra). A férfiaknál és a népesség egészét tartalmazó modellben a COVID-19 változó szignifikáns, pozitív előjelû́ volt (1. táblázat; 1. ábra). Az öngyilkossági esetszámok a 2020 márciusa és decembere közötti járványidőszakban $\exp ^{\beta}$-értékkel nőttek, ahol a $\beta$ a COVID-19 időszakának regressziós együtthatója. A becslés alapján a férfiaknál 1,184-szeresével (95\%-os KI: 1,084-1,292), a népesség egészénél

1. táblázat | Megszakított kvázi-Poisson-idősor-modellek nemenként és a népesség egészére

\begin{tabular}{lccc}
\hline Változók & Férfiak & Nők & Együtt \\
\hline Konstans & $-10,268^{* * *}$ & $-11,581^{* * *}$ & $-10,753^{* * *}$ \\
& $(0,019)$ & $(0,033)$ & $(0,017)$ \\
\hline Idő & $-0,005^{* * *}$ & $-0,004^{* * *}$ & $-0,004$ \\
& $(0,000)$ & $(0,000)$ & $(0,000)$ \\
\hline COVID-19-időszak & $0,168^{* * *}$ & 0,095 & $0,151 * * *$ \\
& $(0,045)$ & $(0,076)$ & $(0,040)$ \\
\hline Cos1 & $-0,142 * * *$ & $-0,105 * * *$ & $-0,133 * * *$ \\
& $(0,014)$ & $(0,024)$ & $(0,013)$ \\
\hline Cos2 & $-0,006$ & $-0,032$ & $-0,013$ \\
& $(0,014)$ & $(0,024)$ & $(0,013)$ \\
\hline Sin1 & $0,043 * *$ & 0,014 & $0,036 * *$ \\
& $(0,014)$ & $(0,024)$ & $(0,013)$ \\
\hline Sin2 & 0,007 & 0,006 & 0,007 \\
& $(0,014)$ & $(0,023)$ & $(0,013)$ \\
\hline
\end{tabular}

${ }^{*} \mathrm{p}<0,05,{ }^{*} \mathrm{p}<0,01,{ }^{*}{ }^{*} \mathrm{p}<0,001 ;$ zárójelben standard hibák

COVID-19 = koronavírus-betegség 2019
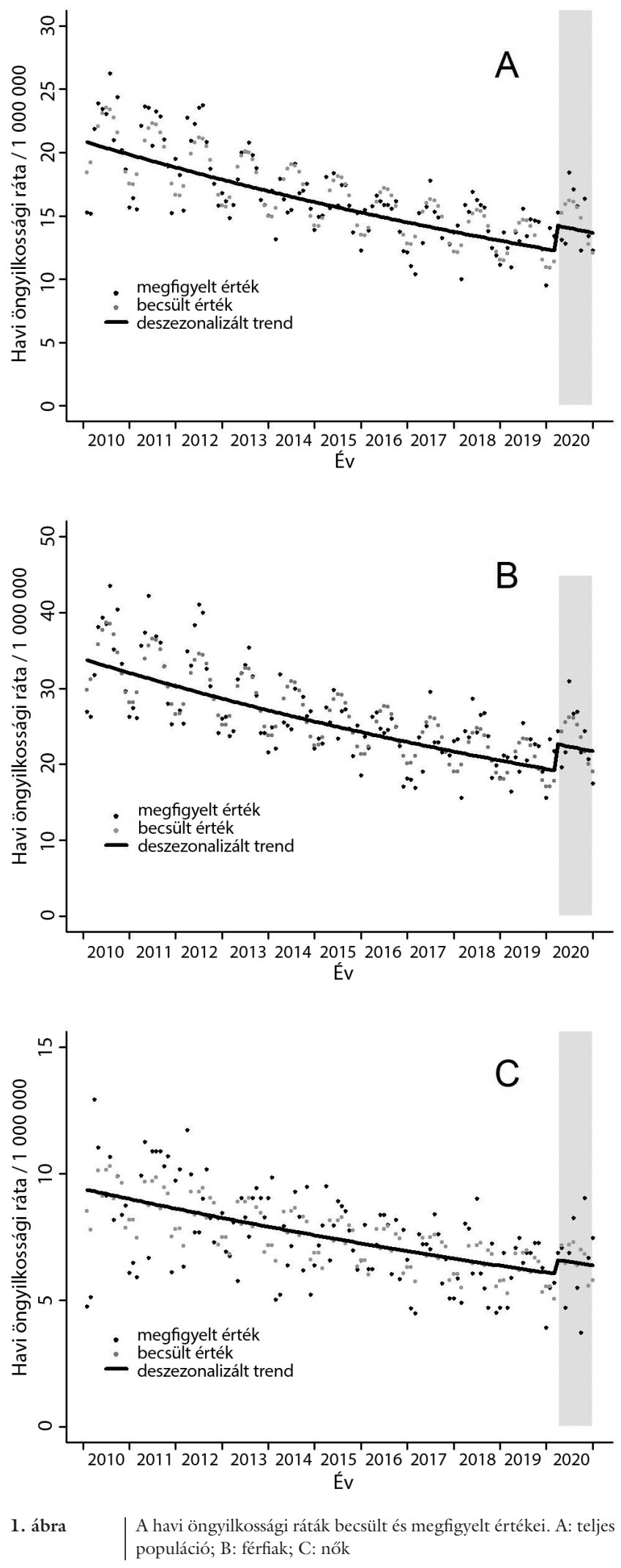

pedig 1,163-szorosával (95\% KI: 1,075-1,258) több öngyilkosság történt, mint abban az esetben, ha a koronavírus-járvány nem következett volna be. Esetszámban kifejezve a pandémia alatti hónapokban 1100 férfi vetett véget önkezúleg életének, míg a tényellentétes állapot 
szerint 929 esetnek „kellett volna” bekövetkeznie (2019ben, az adott hónapokban, 961 haláleset történt). A népesség egészében a megfigyelt esetek száma a 2020. március és december közötti időszakban 1438 volt, míg a tényellentétes állapot szerint 1236 esetnek „kellett volna” bekövetkeznie (2019 ugyanezen időszakában pedig 1294 esetet regisztráltak).

Eredményeink robusztussága érdekében szenzitivitási elemzést végeztünk, és a modelleket rövidebb időszakokra is lefuttattuk. A 2015 és 2020 közti időszakra kapott eredmények megegyeztek a korábbiakkal. A járvány szignifikánsan emelte a suicid ráta szintjét a férfiaknál és a népesség egészében, de nem befolyásolta a nókét. A hibatagok autokorrelációjának vizsgálata alapján nem találtuk bizonyítékát annak, hogy az öngyilkosság aktuális értéke szignifikánsan függne a korábbi hónap (késleltetett) értékétól, a késleltetések a határértékeken belül nem tértek el a nullától.

\section{Megbeszélés}

Hazánk suicid rátája az 1980-as évek végétól többé-kevésbé monoton, erőteljesen csökkenő trendet mutatott $[30,31]$. A 2020. évi adatokat kiértékelve elmondhatjuk, hogy a magyar suicid halálozásnak ez a több évtizede tartó, majdnem monoton módon csökkenő trendje elakadt, és a tavalyi évben, elsősorban a férfiaknál, kifejezett emelkedés mutatkozott. Mint a bevezetóben említettük, a legtöbb eddig publikált, más országokban elvégzett vizsgálat inkább a suicid ráták csökkenéséről/ változatlanságáról, mintsem azok emelkedésérôl számolt be a COVID-19-járvány kitörése utáni időszak vonatkozásában. A külföldi, és a cikkünkben ismertetett hazai eredmények közötti diszkrepanciát több tényező is okozhatja. Így a korábbi vizsgálatok jellemzően rövidebb időszakokból (a járvány kezdeti hónapjaiból) származó adatokat dolgoztak fel, míg a miénk a teljes 2020as évre vonatkozóakat. Ennek azért van jelentősége, mivel egyes elméletek szerint a társadalom nagy részét érintő katasztrófahelyzetek a szociális kohézió átmeneti erősödése miatt időlegesen képesek csökkenteni a suicid rátát $[14,20,21,26]$. Az eltérés egy további, spekulatív magyarázata lehet, hogy hazánkban, melynek öngyilkossági aránya a 20. század második felében évtizedeken át a legmagasabb volt a világon (és az azóta bekövetkező jelentős csökkenés dacára még jelenleg is a világ 20 legmagasabb suicid rátájú országának egyike vagyunk), az öngyilkosság társadalmi elfogadottsága feltételezhetően magas, így krízishelyzetben honfitársaink valószínúleg könnyebben tekintenek „megoldásként” az öngyilkosságra $[30,31]$. Az eltérés egy további lehetséges magyarázata lehet, hogy a gazdagabb országok (amelyekben az eddigi vizsgálatok nagy részét végezték) egészségügyi és szociális ellátórendszerei rendelkeztek annyi, a járványnak a mentális egészséget számtalan különféle módon romboló hatását ellensúlyozó pufferkapacitással, hogy ezek a káros hatások nem jelenhettek meg a befejezett suicidiumok szintjén [20]. Ehhez kapcsolódóan jegyeznénk meg, hogy hazánkban sok olyan - csupán a járványügy szempontjait szem elött tartva elképzelhető, hogy indokolt - intézkedés történt (például egyes pszichiátriai osztályoknak a COVID-19-ellátásra való „átállítása” / kiürítése/elköltöztetése, a pszichiáterek átvezénylése a COVID-19-ellátó osztályokra vagy a 65 évnél idősebb orvosok mentesítése a közvetlen betegellátás alól), amely a pszichiátriai-addiktológiai ellátás elérhetőségét a kliensek számára megnehezítette. Mivel az (ellátatlan) addiktológiai és pszichiátriai betegségek az öngyilkosság legfontosabb rizikófaktoraiként ismertek, igencsak plauzibilis lehetőségként merül fel, hogy a fenti intézkedések összefüggnek az észlelt suicid többlethalálozással. Az észlelt nemi különbségekre szintén csak spekulatív magyarázatunk van: úgy véljük, hogy a pandémiát kísérő kedvezőtlen gazdasági-financiális jelenségek (például a munkahely/jövedelem átmeneti vagy tartós elvesztése) a társadalmi helyzethez és a nemi szerepekhez kapcsolódó elvárások különbségei miatt a férfiakat érintik elsősorban.

Vizsgálatunk, annak módszertanából fakadó, fó limitációja, hogy nem alkalmas arra, hogy egyértelmú bizonyítékot szolgáltasson a COVID-19 kitörése és az emelkedő suicid ráta közötti ok-okozati kapcsolat létezésére, még kevésbé arra, hogy hozzásegítsen az ezt a lehetséges kapcsolatot mediáló tényezók azonosításához. Következésképpen a járvány idején emelkedő suicid ráta elleni specifikus panáceát sem tudunk kínálni; észszerúnek tưnik azonban, hogy olyan, a hazai és a nemzetközi irodalomban részletesen taglalt módszerek hozhatnak javulást, mint a járvánnyal kapcsolatos médiatartalmak megfelelő (nem pánikkeltő) elkészítése, a munkájukat elvesztők minél gyorsabb elhelyezkedését célzó munkaerópiaci intézkedések bevezetése, az új és a már ismert pszichiátriai betegek számára az ellátórendszerbe való gyors bekerülés biztosítása stb. [14, 20].

Összefoglalva, eredményeink a világ más országaiból származó vizsgálatok túlnyomó többségétől eltérően azt mutatják, hogy hazánkban a COVID-19 kitörése (azaz 2020 márciusa) után a befejezett öngyilkosságok száma növekedésnek indult, amit a leginkább a férfiak között lehetett megfigyelni. Ez egyben a hazai suicid ráta több évtizede tartó csökkenő trendjének (átmeneti?) megtorpanását is jelenti. A hazai és a nemzetközi eredmények közötti eltérés további vizsgálatokat igényel, ezért munkacsoportunk a közeljövőben tervezi az adatok részletesebb, finomabb elemzésével tisztázni a kérdést.

Anyagi támogatás: A közlemény megírása, illetve a kapcsolódó kutatómunka anyagi támogatásban nem részesült.

Szerzői munkamegosztás: O. P., D. P.: Irodalomkutatás, a kézirat megírása. B. L.: Adatgyújtés, statisztikai számítások, a kézirat elkészítése. N. A., K. B., R. Z.: Részvétel a kézirat elkészítésében. 
Érdekeltségek: A szerzőknek nincsenek a cikk tartalmát potenciálisan befolyásoló, illetve annak elkészítését motiváló érdekeltségeik.

\section{Irodalom}

[1] She J, Jiang J, Ye L, et al. 2019 novel coronavirus of pneumonia in Wuhan, China: emerging attack and management strategies. Clin Transl Med. 2020; 9: 19.

[2] Vajer P, Csenteri O, Szabó J, et al. Family medicine during COVID-19 pandemic. [Háziorvoslás a COVID-19-járvány idején.] Orv Hetil. 2020; 161: 1699-1705. [Hungarian]

[3] Hanaei S, Mohebi F, Moradi-Lakeh M, et al. The epidemiologic aspects of COVID-19 outbreak: spreading beyond expectations. Adv Exp Med Biol. 2021; 1318: 61-79.

[4] Ji W. Coronaviruses: what should we know about the characteristics of viruses? Adv Exp Med Biol. 2021; 1318: 23-39.

[5] Centers for Disease Control and Prevention. Human coronavirus types. CDC, Atlanta, GA, Feb 15, 2020. Available from: https://www.cdc.gov/coronavirus/types.html.

[6] Eskian M, Rezaei N. Clinical manifestations of COVID-19. Adv Exp Med Biol. 2021; 1318: 179-196.

[7] Lou JJ, Movassaghi M, Gordy D, et al. Neuropathology of COVID-19 (neuro-COVID): clinicopathological update. Free Neuropathol. 2021; 2: 2.

[8] Rezaei N, Ashkevarian S, Fathi MK, et al. Introduction on coronavirus disease (COVID-19) pandemic: the global challenge. Adv Exp Med Biol. 2021; 1318: 1-22.

[9] European Centre for Disease Prevention and Control. Factsheet about Middle East respiratory syndrome coronavirus (MERS $\mathrm{CoV})$. ECDC, Stockholm. Available from: https://www.ecdc. europa.eu/en/middle-east-respiratory-syndrome-coronavirus/ factsheet.

[10] Kordzadeh-Kermani E, Khalili H, Karimzadeh I. Pathogenesis, clinical manifestations and complications of coronavirus disease 2019 (COVID-19). Future Microbiol. 2020; 15: 1287-1305

[11] Delavari F, Varzaneh FN, Rezaei N. Neurologic manifestations of COVID-19. Adv Exp Med Biol. 2021; 1318: 343-353.

[12] Guerrero JI, Barragán LA, Martínez JD, et al. Central and peripheral nervous system involvement by COVID-19: a systematic review of the pathophysiology, clinical manifestations, neuropathology, neuroimaging, electrophysiology, and cerebrospinal fluid findings. BMC Infect Dis. 2021; 21: 515.

[13] Rogers JP, Watson CJ, Badenoch J, et al. Neurology and neuropsychiatry of COVID-19: a systematic review and meta-analysis of the early literature reveals frequent CNS manifestations and key emerging narratives. J Neurol Neurosurg Psychiatry 2021; 92: 932-941.

[14] Osváth P. Psychological outcome of COVID-19 pandemic. How can we prepare for a psychodemic crisis? [A COVID19-pandémia mentálhigiénés következményei. Hogyan tudunk felkészülni a pszichodémiás krízisre?] Orv Hetil. 2021; 162: 366-374. [Hungarian]

[15] Hawton K, Lascelles K, Brand F, et al. Self-harm and the COVID-19 pandemic: A study of factors contributing to selfharm during lockdown restrictions. J Psychiatr Res. 2021; 137: $437-443$.
[16] Rogers JP, Chesney E, Oliver D, et al. Suicide, self-harm and thoughts of suicide or self-harm in infectious disease epidemics: a systematic review and meta-analysis. Epidemiol Psychiatr Sci. 2021; 30: e32.

[17] Rihmer Z. Suicide risk in mood disorders. Curr Opin Psychiatry 2007; 20: 17-22.

[18] Rihmer Z, Angst J. Mood Disorders: Epidemiology. In: Sadock BJ, Sadock VA, Ruiz P. (eds.) Kaplan \& Sadock's comprehensive textbook of psychiatry (9th edition). Lippincott Williams \& Wilkins, Philadelphia, PA, 2009; pp. 1645-1652.

[19] Puig-Amores I, Cuadrado-Gordillo I, Parra GM-M. Suicide and health crisis in Extremadura: impact of confinement during COVID-19. Trauma Care 2021; 1: 38-48.

[20] John A, Pirkis J, Gunnell D, et al. Trends in suicide during the Covid-19 pandemic. BMJ 2020; 371: $\mathrm{m} 4352$.

[21] Deisenhammer EA, Kemmler G. Decreased suicide numbers during the first 6 months of the COVID-19 pandemic. Psychiatry Res. 2021; 295: 113623

[22] Appleby L, Richards N, Ibrahim S, et al. Suicide in England in the COVID-19 pandemic: early observational data from real time surveillance. Lancet Reg Health Eur. 2021; 4: 100110.

[23] Leske S, Kõlves K, Crompton D, et al. Real-time suicide mortality data from police reports in Queensland, Australia, during the COVID-19 pandemic: an interrupted time-series analysis. Lancet Psychiatry 2021; 8: 58-63.

[24] Barbic D, Scheuermeyer FX, Barbic SP, et al. Suicide deaths in British Columbia during the first wave of the COVID-19 pandemic. Can J Psychiatry 2021 May 17. 7067437211018398. [Epub ahead of print]

[25] Pirkis J, John A, Shin S, et al. Suicide trends in the early months of the COVID-19 pandemic: an interrupted time-series analysis of preliminary data from 21 countries. Lancet Psychiatry 2021; 8: 579-588. [Erratum: Lancet Psychiatry 2021 Jun 4.] [Erratum: Lancet Psychiatry 2021 Aug 27.]

[26] Radeloff D, Papsdorf R, Uhlig K, et al. Trends in suicide rates during the COVID-19 pandemic restrictions in a major German city. Epidemiol Psychiatr Sci. 2021; 30: el6.

[27] Osaki Y, Otsuki H, Imamoto A, et al. Suicide rates during social crises: changes in the suicide rate in Japan after the Great East Japan earthquake and during the COVID-19 pandemic. J Psychiatr Res. 2021; 140: 39-44.

[28] Tanaka T, Okamoto S. Increase in suicide following an initial decline during the COVID-19 pandemic in Japan. Nat Hum Behav. $2021 ; 5: 229-238$.

[29] Zortea TC, Brenna CTA, Joyce M, et al. The impact of infectious disease-related public health emergencies on suicide, suicidal behavior, and suicidal thoughts. Crisis 2020: 1-14.

[30] Németh A, Döme P, Drótos G, et al. Statistics on completed suicides committed in Hungary in the period between 2000 and 2019. [A 2000 és 2019 közötti időszakban Magyarországon elkövetett befejezett öngyilkosságok statisztikai elemzése.] Orv Hetil. 2021; 162: 1283-1296. [Hungarian]

[31] Rihmer Z, Gonda X, Kapitány B, et al. Suicide in Hungary-epidemiological and clinical perspectives. Ann Gen Psychiatry 2013; 12: 21 .

(Döme Péter dr.,

Budapest, Balassa u. 6., 1083 e-mail: dome_peter@yahoo.co.uk)

A cikk a Creative Commons Attribution 4.0 International License (https://creativecommons.org/licenses/by/4.0/) feltételei szerint publikált Open Access közlemény, melynek szellemében a cikk bármilyen médiumban szabadon felhasználható, megosztható és újraközölhetö, feltéve, hogy az eredeti szerző és a közlés helye, illetve a CC License linkje és az esetlegesen végrehajtott módosítások feltüntetésre kerülnek. (SID_1) 